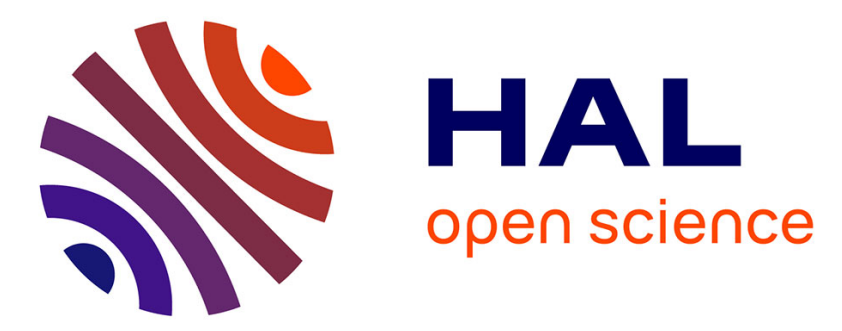

\title{
Components Are Present in Human Fetal Ovary Before Follicle Formation
}

R.-M Törmälä, Minna Mäentausta, Jouni Lakkakorpi, Annikki Liakka, Juha S. Tapanainen, Tommi E. Vaskivuo

\section{- To cite this version:}

R.-M Törmälä, Minna Mäentausta, Jouni Lakkakorpi, Annikki Liakka, Juha S. Tapanainen, et al.. Components Are Present in Human Fetal Ovary Before Follicle Formation. Molecular and Cellular Endocrinology, 2008, 289 (1-2), pp.10. 10.1016/j.mce.2008.01.029 . hal-00531995

\section{HAL Id: hal-00531995 \\ https://hal.science/hal-00531995}

Submitted on 4 Nov 2010

HAL is a multi-disciplinary open access archive for the deposit and dissemination of scientific research documents, whether they are published or not. The documents may come from teaching and research institutions in France or abroad, or from public or private research centers.
L'archive ouverte pluridisciplinaire HAL, est destinée au dépôt et à la diffusion de documents scientifiques de niveau recherche, publiés ou non, émanant des établissements d'enseignement et de recherche français ou étrangers, des laboratoires publics ou privés. 


\section{Accepted Manuscript}

Title: Zona Pellucida Components Are Present in Human Fetal Ovary Before Follicle Formation

Authors: R.-M Törmälä, Minna Mäentausta, Jouni Lakkakorpi, Annikki Liakka, Juha S. Tapanainen, Tommi E. Vaskivuo

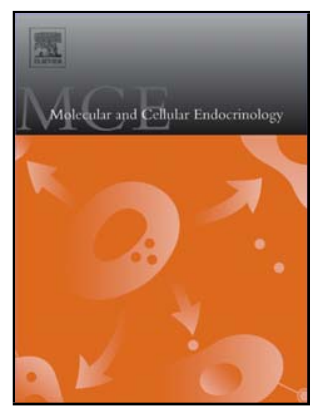

PII: S0303-7207(08)00026-9

DOI: doi:10.1016/j.mce.2008.01.029

Reference: MCE 6804

To appear in: Molecular and Cellular Endocrinology

Received date: $\quad 18-10-2007$

Revised date: 2-1-2008

Accepted date: $\quad 23-1-2008$

Please cite this article as: Törmälä, R.-M., Mäentausta, M., Lakkakorpi, J., Liakka, A., Tapanainen, J.S., Vaskivuo, T.E., Zona Pellucida Components Are Present in Human Fetal Ovary Before Follicle Formation, Molecular and Cellular Endocrinology (2007), doi:10.1016/j.mce.2008.01.029

This is a PDF file of an unedited manuscript that has been accepted for publication. As a service to our customers we are providing this early version of the manuscript. The manuscript will undergo copyediting, typesetting, and review of the resulting proof before it is published in its final form. Please note that during the production process errors may be discovered which could affect the content, and all legal disclaimers that apply to the journal pertain. 
Zona Pellucida Components Are Present in Human Fetal Ovary Before Follicle Formation

R-M Törmäläa, ${ }^{\mathrm{a}, \mathrm{b}}$, Minna Mäentausta ${ }^{\mathrm{a}, \mathrm{b}}$, Jouni Lakkakorpi ${ }^{\mathrm{b}, \mathrm{c}}$, Annikki Liakka ${ }^{\mathrm{d}}$, Juha S. Tapanainen $^{\mathrm{a}, \mathrm{b}}$, Tommi E. Vaskivuo ${ }^{\mathrm{a}, \mathrm{b}, \mathrm{e}, *}$

${ }^{\mathrm{a}}$ Department of Obstetrics and Gynaecology, University of Oulu, Oulu, Finland

${ }^{\mathrm{b}}$ Clinical Research Center, Oulu University Hospital, Oulu, Finland

${ }^{c}$ Family Federation of Finland, Oulu, Finland

${ }^{\mathrm{d}}$ Department of Pathology, University of Oulu, Oulu, Finland

${ }^{\mathrm{e}}$ Department of Clinical Chemistry, University of Oulu, Finland

${ }^{*}$ Corresponding author:

Tommi Vaskivuo, M.D., Ph.D.,

Departments of Clinical Chemistry and

Obstetrics and Gynaecology,

Clinical Research Center,

P.O. Box 5000,

FI-90014, University of Oulu,

Finland

Tel. $+358-8-3154432$

Fax. $+358-8-315-4492$

Email: tommi.vaskivuo@oulu.fi 
Keywords: fetal ovary, FIGLA, folliculogenesis, ZP1, ZP3

\begin{abstract}
The zona pellucida is a glycoprotein matrix surrounding oocytes and early-stage embryos in mammals. To elucidate the roles of the zona pellucida glycoproteins ZP1 and ZP3 and their key regulatory factor FIGLA in human ovarian development and folliculogenesis, their expression and localization was studied in human fetal and adult ovaries. FIGLA mRNA and ZP3 mRNA/protein were localized mainly in the oocytes, and during fetal development their maximal expression was observed around the 20th week, the time of follicle formation. The expression of ZP1 mRNA was low both in fetal and adult ovaries. Present findings demonstrate that ZP3 and FIGLA transcripts are expressed in the oocytes from early ovarian development. The function of ZP proteins during early fetal life is not clear, but the simultaneous expression of FIGLA and ZP3 suggests, that they may have a role in the development of primordial follicle before zona pellucida formation.
\end{abstract}




\section{Introduction}

The zona pellucida (ZP) is an extracellular matrix that surrounds the mammalian oocyte and early-stage embryo. The human ZP consists of at least four glycoproteins, zona pellucida glycoprotein 1-4 (ZP1-4) (Sacco et al., 1981; Shabanowitz and O'Rand, 1988; Hughes and Barrat, 1999; Lefievre et al., 2004). Current understanding of the structure and function of the zona pellucida is mainly based on studies in mice, in which the ZP is composed of three glycoproteins, Zp1-3 (Bleil and Wassarman, 1980b). Mouse Zp3 functions as a primary sperm receptor and plays an important role in binding of spermatozoa to the zona pellucida and in initiation of the acrosome reaction (Bleil and Wassarman, 1980a; Wassarman, 1988; Wassarman, 2005), while Zp1 functions as a key structural component maintaining the three-dimensional structure of the zona matrix (Greve and Wassarman, 1985; Bleil et al., 1988; Wassarman, 1988). Zp2 serves as a secondary receptor for sperm during the fertilization in mice (Bleil et al., 1988). However, there are several well-known species-specific differences in the function of ZP proteins (Prasad et al., 1996; Yurewicz et al., 1998; Bedford, 1977; Rankin et al., 1998; 2003) and it is therefore difficult to apply these findings directly to humans. We have previously shown that in humans, sequence variations in the genes for ZP1 and ZP3 but not in ZP2 and ZP4 can be associated with fertilization failure in in vitro fertilization (Männikkö et al., 2005).

The expression of ZP genes is under direct regulation of a transcription factor termed Factor in the Germ Line Alpha (Figla) (Liang et al., 1997; Bayne et al., 2004), which is essential for the formation of primordial follicles and survival of the oocyte in mice (Soyal et al., 2000). FIGLA is expressed in human fetal (Bayne et al., 2004) and adult 
(Huntriss et al., 2002; Bayne et al., 2004) ovaries, but its role is still not well understood.

The aim of the study was to elucidate the roles of ZP1 and ZP3, the key candidate components of the zona pellucida in humans (Männikkö et al., 2005), and their regulatory factor FIGLA during human ovarian development by analysing the expression and localization of ZP1, ZP3 and FIGLA mRNA, and ZP3 protein in human fetal and adult ovaries. 


\section{Material and Methods}

\subsection{Tissue Samples}

Ovarian samples from 10 fetuses (fetal age 11-21 wk) were obtained after spontaneous or therapeutic abortions. Ovarian samples from 6 fetuses (23-37 wk) were obtained after intrauterine fetal death followed by spontaneous or induced deliveries or Caesarean sections. In addition, ovaries from two neonates (23 and 31 wk) who died because of perinatal asphyxia or infection within $8 \mathrm{~h}$ after birth were studied (Table 1). All fetuses and neonates had normal karyotypes. Samples with visible autolysis were excluded from the study. Adult ovarian tissue was obtained from seven patients undergoing ovariectomy due to endometriosis. All samples were fixed in $4 \%$ buffered formaldehyde for $24 \mathrm{~h}$, rehydrated, and embedded in paraffin. Histological sections $(4 \mu \mathrm{m})$ were cut and processed for in situ hybridization and immunohistochemistry. The study was approved by the Ethics Committee of Oulu University Hospital and a permit to study human autopsy tissue was obtained from the National Authority for Medicolegal Affairs.

\subsection{In situ hybridization}

Expressed Sequence Tags (EST) clones (image clone 1837179 for ZP1, 5724267 for ZP3 and 5744748 for FIGLA) were acquired from MRC geneservice (Cambridge, UK). Plasmid DNA preparations were made using PhoenIX ${ }^{\mathrm{TM}}$ Maxiprep Kits (Qbiogene, Morgan Irvine, CA, USA) according to the instructions of the manufacturer. Templates were linearized by digestion with suitable restriction enzymes. DNA was purified according to the instructions in the QIAquick ${ }^{\circledR}$ PCR Purification Kit (QIAGEN, Hilden, Germany). 
In situ hybridization was performed as previously described (Vaskivuo et al., 2005). Briefly, the antisense and sense probes were transcribed from the linearized templates by T7, SP6 or T3 RNA polymerases (Promega Corporation, Madison, WI, USA) and labelled with ${ }^{35}$ S-UTP (GE Healthcare, UK). Before hybridization the ovary samples were treated with proteinase $\mathrm{K}(10 \mathrm{mg} / \mathrm{mL})$. The probe $(45 \mu \mathrm{L})$ was applied to the tissue sections (1.5-2 million cpm/slide), sealed with a plastic coverslip and hybridized in a humidified chamber at $56^{\circ} \mathrm{C}$ for 16 hours. The sections were digested with RNAse, vacuum-dried and coated with photographic emulsion Kodak NTB (Kodak, Rochester, NY, USA) diluted 1:1 with 1\% glycerol. The slides were exposed for 11 to 25 days and developed using Kodak Professional D-19 developer (Kodak, Rochester, NY, USA) for 3.5 min and fixed using Kodak Professional fixer (Kodak, Rochester, NY, USA) for $2 \mathrm{~min}$. The slides were counterstained with haematoxylin.

All samples were evaluated by two independent observers (R-M.T. and T.E.V.) by using light and dark field microscopy. The mRNA expression levels were semiquantified by scoring the samples into degrees of intensity from $+/$ - (lowest) to +++ (highest) (Table 1).

\subsection{Immunohistochemistry}

Immunohistochemistry was performed using Vectastain Elite $\mathrm{ABC}$ Kits (Vectorlaboratories, Burlingame, CA), as previously described (Vaskivuo et al., 2001). Briefly, paraffin sections were deparaffinized in xylene and hydrated gradually through a series of graded alcohols. For adult tissue, standard sodium citrate epitope retrieval was used. Endogenous peroxidase activity was blocked with 3\% hydrogen peroxide in methanol. Polyclonal ZP3 antibody obtained from Aviva Systems Biology (San Diego, Ca, USA) was used at 1:200 and incubated for $2 \mathrm{~h}$ at RT. For adult tissue, 
fetal calf serum was added to the primary antibody (final concentration $5 \%$ ) in order to block non-specific binding and incubation was overnight at $+4{ }^{\circ} \mathrm{C}$. A colour reaction was produced with diaminobenzidine. 


\section{Results}

\subsection{ZP3 is abundantly expressed during mid-gestation}

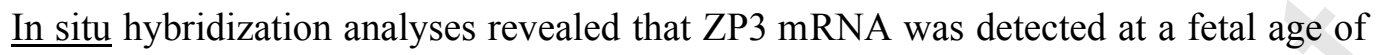
11 weeks (Table 1, ZP3) (Fig. 1a A, B) and it was markedly increased towards midterm, reaching its maximum around the 20th week, coinciding with the formation of follicles (Fig. 1a C-F). Thereafter its levels remained high until the 30th week (Table 1, ZP3) (Fig. 1a G, H). Localization of expression was difficult to determine before follicle formation, but after that all oocytes clearly expressed ZP3 mRNA. As a result of high expression inside the follicles, it was difficult to exclude possible expression in the granulosa cells. During the last few weeks of pregnancy, ZP3 mRNA levels clearly decreased and at birth low mRNA expression, equal to that observed in the first trimester, was detected (Fig. 1a I, J).

Similarly to mRNA, immunohistochemical analysis demonstrated that ZP3 protein was already present at the 11th week of fetal life (Fig. 2 A, B). High expression could be seen at the age of 17 weeks, but its localization was difficult to determine (Fig. 2 C, D). The strongest immunostaining coincided with the high mRNA expression between 20th and 30th weeks (Fig. 2 E-H). During this stage and thereafter (Fig 2 I, J), the most intensive staining was observed in the follicles, especially in the oocytes, and minimal or negligible staining was observed in the stroma.

\subsection{Low ZP1 expression is present from mid-gestation until birth}

The expression of ZP1 mRNA was markedly lower than that of ZP3. Minimal or negligible expression of ZP1 mRNA was detected from 11th week (Fig. 1b A, B) until the 25th week (Table 1, ZP1) (Fig. 1b C-F). Thereafter it increased slightly and 
remained constant until birth (Table 1, ZP1) (Fig. 1b G-J). Owing to the generally low level of ZP1 mRNA expression, determining its localization was ambiguous. There was no clear difference in the signal levels between oocytes and granulosa cells at any stage of fetal life.

\subsection{FIGLA expression is elevated during the second and third trimester}

FIGLA mRNA was detected at the 11th week (Table 1, FIGLA) (Fig. 1c A, B) and its expression remained relatively low until the 20th week (Table 1, FIGLA)(Fig. 1c C, D). Thereafter the expression increased (Fig. 1c E-H) coinciding with the formation of ovarian follicles, and moderately high FIGLA mRNA expression was observed until birth (Fig. 1c I, J). After follicle formation FIGLA mRNA could be clearly localized to the oocytes. However, minimal expression in the granulosa cells could not be excluded, especially during early fetal life.

\subsection{ZP and FIGLA expression in adult ovary}

ZP3 mRNA was detected mainly in the oocytes of the adult ovary, but the expression in granulosa cells could not be excluded (Fig. 3 A-D). Staining of ZP3 protein was observed in the oocytes (Fig. 3 E-H) and it was also detected in granulosa cells until the secondary follicle stage, while only negligible staining was found in antral follicles. Minimal or negligible ZP1 mRNA was observed in adult ovaries (Fig. 3 IL). Moderate expression of FIGLA mRNA was detected mainly in the oocytes (Fig. 3 $\mathrm{M}-\mathrm{P})$. 


\section{Discussion}

The present results demonstrate that ZP3 and FIGLA mRNA are expressed during human ovarian development. Expression of both mRNAs was detected from the 11th week onwards. Maximal expression of both FIGLA and ZP3 mRNA was observed around the 20th week of fetal life, the time of follicle formation. Expression of FIGLA mRNA remained high and stable until term, while ZP3 mRNA expression decreased to some extent during the last trimester. Only minimal or low ZP1 mRNA expression was detected during ovarian development.

The up-regulation of ZP3 and FIGLA mRNA expression coincided with the formation of ovarian follicles. The simultaneous expression of these factors supports the concept that ZP genes are transcriptional targets of Figla (Liang et al., 1997). The common understanding is that the zona pellucida is formed at the primary follicle stage (Kierszenbaum, 2007). The expression of ZP genes before the formation of primary follicles suggests that crucial ZP components are already present at earlier stages of ovarian development. The increased expression of FIGLA mRNA around the 20th week is supported by the results of a previous study showing a 40 -fold increase in the expression of FIGLA transcripts in human fetal ovaries between 14-19 weeks of gestation (Bayne et al., 2004). Our findings indicate that FIGLA is mainly expressed in the oocytes during ovarian development and folliculogenesis. This is in concordance with the results of previous studies on human ovaries (Huntriss et al., 2002; Bayne et al., 2004). The importance of FIGLA in the formation of ovarian follicles is emphasized by the results of studies in knockout mice, in which the formation of primordial follicles is disrupted owing to the inability of oocytes to interact with granulosa cells (Soyal et al., 2000). 
The localization of mammalian ZP proteins in the ovary has been controversial and there is no clear consensus as to whether or not human ZP proteins are synthesized in the oocyte, granulosa cells or both. While there are studies suggesting that ZP3 protein is expressed both in oocytes and granulosa cells (Grootenhuis et al., 1996), there is growing evidence that during human folliculogenesis ZP proteins are expressed in the oocytes (Ebersbaecher et al., 2001; Huntriss et al., 2002; Lefievre et al., 2004). In the present study, ZP3 mRNA was mainly expressed in the oocyte both in the fetal and adult ovaries. Owing to its strong expression there, it was difficult unambiguously to exclude minimal expression in the granulosa cells. However, it was clear that the oocytes showed greater mRNA expression than granulosa cells. During mid-gestation, dense spherical staining of ZP3 mRNA was shown around some of the oocytes, suggesting that the zona matrix is formed at the time of follicle formation.

Due to the low level of expression of ZP1 mRNA it was difficult to determine its exact localization. While ZP1 has been previously found in oocytes of adult human ovaries (Eberspaecher et al., 2001; Lefievre et al., 2004), to our knowledge there are no reports concerning the expression of ZP1 in human fetal ovaries. The low expression level, which was somewhat increased during the last trimester, suggests that ZP1 may not have a major role in follicle formation during early ovarian development in humans, although it is believed to be important later as a protein maintaining the structure of the zona pellucida in mammals (Greve and Wassarman, 1985; Bleil et al., 1988; Wassarman, 1988). The present observations concerning low ZP1 mRNA expression are in agreement with previous notions that $\mathrm{Zp} 1$ is the least abundant of the zona glycoprotein transcripts in mice (Epifano et al., 1995), and Zp1 protein comprises approximately only $9 \%$ of the total zona protein content (Wassarman et al., 1989). 
Regulation of primordial follicle formation during mammalian development is poorly understood, and we are now beginning to understand piece by piece the mechanisms underlying these complex events. Studies using FIGLA null mice have demonstrated the critical role of this regulatory factor in the initiation of folliculogenesis (Soyal et al., 2000). Our results support these findings as expression of FIGLA is clearly increased during the time of primordial follicle formation. Moreover, an interesting finding here is that the expression of ZP3, as demonstrated both at mRNA and protein level, was also increased during this stage of ovarian development. The significant expression of FIGLA and ZP3 during early fetal life suggests that these factors may have a role in the development of primordial follicles before the formation of zona pellucida in humans. 


\section{Acknowledgements}

The authors wish to express their gratitude to Dr. Riitta Herva for kindly collecting the fetal ovarian samples. We also thank Petri Itäranta, $\mathrm{PhD}$, for helping to design the in situ hybridization studies, and Mrs Mirja Ahvensalmi for skillful technical assistance. This study was supported by grants from the Academy of Finland, Finnish Cultural Foundation, Oulu University Hospital, the Oulu University Scholarship Foundation and the Sigrid Jusélius Foundation. 


\section{Figure Legends}

Fig. 1. Expression of ZP3, ZP1 and FIGLA mRNA in human fetal ovaries.

Scale bars $=5 \mu \mathrm{M}$

1a. ZP3 mRNA can be detected in the ovary already at the fetal age of 11 weeks +3 days, bright (A) and dark fields (B). Thereafter the expression increases and clusters in the oocytes (C-H, arrows). During the last weeks of pregnancy the expression decreases (I, J). 27 weeks, sense control (S).

1b. Only minimal ZP1 mRNA is detected in the fetal ovaries (A-F). The expression is slightly increased during last trimester when low staining was observed in the oocytes (G-J, arrows). 27 weeks, sense control (S).

1c. FIGLA mRNA can be detected from 11th week onwards (A-D, arrows). An increase in the expression level coincides with the follicle formation $(\mathrm{E}, \mathrm{F})$. The expression was localized to the oocytes (E, arrow). During last trimester, relatively strong (arrows) expression can be seen (G-J). 27 weeks, sense control (S).

Fig. 2. Expression of ZP3 protein in human fetal ovaries.

ZP3 immunostaining can be observed from the 11th week onwards (A, higher magnification B). At $17+5$ weeks high expression can be seen $(C, D)$. During early ovarian development the localization of the protein is challenging and it is difficult to 
exclude protein staining in the granulosa cells (B, D, arrows). At mid-pregnancy (E, $\mathrm{F}$, arrows) as well as during the last trimester (G-J, arrows) ZP3 staining localizes to the oocytes. Negative control (NC). Scale bars $=5 \mu \mathrm{M}$.

Fig. 3. Expression of ZP3, ZP1 and FIGLA mRNA and ZP3 protein in human adult ovaries.

ZP3 mRNA was mainly localized to the oocytes (primordial follicles: A, B, arrows; antral follicle: C, D. Light and dark field). ZP3 mRNA expression in granulosa cells can not be excluded. Sense control (S). ZP3 protein is localized to the oocytes of primordial (E, arrows) and secondary follicles (F, arrows). Staining in antral follicles is negligible (G). Negative control (H). Only negligible ZP1 mRNA expression can be observed (I-L, arrows). FIGLA mRNA can be detected in primordial follicles (M, N, arrows), but not in the antral follicles $(\mathrm{O}, \mathrm{P})$. Scale bars $=5 \mu \mathrm{M}$. 
Table 1. Expression of ZP1, ZP3 and FIGLA mRNA in human fetal ovaries.

\begin{tabular}{ccccc}
\hline $\begin{array}{c}\text { Age } \\
\text { (weeks } \\
\text { days) }\end{array}$ & $\begin{array}{c}\text { Source of } \\
\text { fetuses }\end{array}$ & ZP1 & ZP3 & FIGLA \\
\hline $11+3$ & s.a. & $+/-$ & + & + \\
12 & i.a. & $+/-$ & + & + \\
13 & i.a. & $+/-$ & na & + \\
15 & i.a. & $+/-$ & + & + \\
16 & s.a. & $+/-$ & ++ & + \\
$17+5$ & s.a. & $+/-$ & ++ & ++ \\
$18+1$ & s.a. & $+/-$ & na & na \\
$19+1$ & s.a. & + & +++ & + \\
$20+6$ & i.a. & $+/-$ & na & + \\
$21+6$ & i.a. & na & +++ & ++ \\
$23+1$ & s.d. & $+/-$ & +++ & ++ \\
$25+6$ & i.d. & + & na & ++ \\
27 & c.s. & + & +++ & ++ \\
$31+2$ & s.d. & na & +++ & ++ \\
$32+3$ & i.d. & + & ++ & ++ \\
$33+4$ & i.d. & + & ++ & ++ \\
$36+2$ & c.s. & na & na & ++ \\
$37+6$ & i.d. & + & + & na \\
\hline
\end{tabular}

s.a. $=$ spontaneous abortion

i.a. $=$ induced abortion

s.d. $=$ spontaneous delivery

i.d. $=$ induced delivery

c.s. $=$ Caesarean section

na $=$ specimen not available 


\section{References}

Bayne, R.A., Martins da Silva, S.J., Anderson R.A., 2004. Increased expression of the FIGLA transcription factor is associated with primordial follicle formation in the human fetal ovary. Mol. Hum. Reprod. 10, 373-381.

Bedford, J.M., 1977. Sperm/egg interaction: The specificity of human spermatozoa. Anat. Rec. 188, 477-487.

Bleil, J.D., Greve, J.M., Wassarman, P.M., 1988. Identification of a secondary sperm receptor in the mouse egg zona pellucida: Role in maintenance of binding of acrosome-reacted sperm to eggs. Dev. Biol. 128, 376-385.

Bleil, J.D., Wassarman, P.M., 1980a. Mammalian sperm-egg interaction: Identification of a glycoprotein in mouse egg zonae pellucidae possessing receptor activity for sperm. Cell 20, 873-882.

Bleil, J.D., Wassarman, P.M., 1980b. Structure and function of the zona pellucida: Identification and characterization of the proteins of the mouse oocyte's zona pellucida. Dev. Biol. 76, 185-202.

Eberspaecher, U., Becker, A., Bringmann, P., van der Merwe, L., Donner, P., 2001. Immunohistochemical localization of zona pellucida proteins ZPA, ZPB and ZPC in human, cynomolgus monkey and mouse ovaries. Cell Tissue Res. 303, 277-287. 
Epifano, O., Liang, L.F., Familari, M., Moos, M.C. Jr, Dean, J., 1995. Coordinate expression of the three zona pellucida genes during mouse oogenesis. Development 121, 1947-1956.

Greve, J.M., Wassarman, P.M., 1985. Mouse egg extracellular coat is a matrix of interconnected filaments possessing a structural repeat. J. Mol. Biol. 181, 253-264.

Grootenhuis, A.J., Philipsen, H.L., de Breet-Grijsbach, J.T., van Duin, M., 1996. Immunocytochemical localization of ZP3 in primordial follicles of rabbit, marmoset, rhesus monkey and human ovaries using antibodies against human ZP3. J. Reprod. Fertil. Suppl. 50, 43-54.

Hughes, D.C., Barratt, C.L., 1999. Identification of the true human orthologue of the mouse Zp1 gene: Evidence for greater complexity in the mammalian zona pellucida? Biochim. Biophys. Acta 1447, 303-306.

Huntriss, J., Gosden, R., Hinkins, M., Oliver, B., Miller, D., Rutherford, A.J., Picton, H.M., 2002. Isolation, characterization and expression of the human factor in the germline alpha (FIGLA) gene in ovarian follicles and oocytes. Mol. Hum. Reprod. 8, 1087-1095.

Kierszenbaum, A.L., 2007. Histology and Cell Biology: an Introduction to Pathology. 2nd Edition. pp. 615-616. Mosby Elsevier. Philadelphia, PA .

Lefievre, L., Conner, S.J., Salpekar, A., Olufwobi, O., Ashton, P., Pavlovic, B., Lenton, W., Afnan, M., Brevis, I.A., Monk, M., Hughes, D.C., Barratt, C.L., 2004. 
Four zona pellucida glycoproteins are expressed in the human. Hum. Reprod. 19, $1580-1586$.

Liang, L., Soyal, S.M., Dean, J., 1997. FIGalpha, a germ cell specific transcription factor involved in the coordinate expression of the zona pellucida genes. Development 124, 4939-4947.

Mannikko, M., Tormala, R.M., Tuuri, T., Haltia, A., Martikainen, H., Ala-Kokko, L., Tapanainen, J.S., Lakkakorpi, J.T., 2005. Association between sequence variations in genes encoding human zona pellucida glycoproteins and fertilization failure in IVF. Hum. Reprod. 20, 1578-1585.

Prasad, S.V., Wilkins, B., Skinner, S.M., Dunbar, B.S., 1996. Evaluating zona pellucida structure and function using antibodies to rabbit $55 \mathrm{kDa} \mathrm{ZP}$ protein expressed in baculovirus expression system. Mol. Reprod. Dev. 43, 519-529.

Rankin, T.L., Coleman, J.S., Epifano, O., Hoodbhoy, T., Turner, S.G., Castle, P.E., Lee, E., Gore-Langton, R., Dean, J. 2003. Fertility and taxon-specific sperm binding persist after replacement of mouse sperm receptors with human homologs. Dev. Cell 5, 33-43.

Rankin, T., Talbot, P., Lee, E., Dean, J., 1999. Abnormal zonae pellucidae in mice lacking ZP1 result in early embryonic loss. Development 126, 3847-3855. 
Rankin, T.L., Tong, Z.B., Castle, P.E., Lee, E., Gore-Langton, R., Nelson, L.M., Dean, J., 1998. Human ZP3 restores fertility in Zp3 null mice without affecting order-specific sperm binding. Development 125, 2415-2424.

Sacco, A.G., Yurewicz, E.C., Subraminian, M.G., DeMayo, F.J., 1981. Zona pellucida composition: Species cross reactivity and contraceptive potential of antiserum to a purified pig zona antigen (PPZA). Biol. Reprod. 25, 997-1008.

Shabanowitz, R.B., O'Rand, M.G., 1988. Characterization of the human zona pellucida from fertilized and unfertilized eggs. J. Reprod. Fertil. 82, 151-161.

Soyal, S.M., Amleh, A., Dean, J., 2000. FIGalpha, a germ cell-specific transcription factor required for ovarian follicle formation. Development 127, 4645-4654.

Vaskivuo, T.E., Anttonen, M., Herva, R., Billig, H., Dorland, M., te Velde, E.R., Stenback, F., Heikinheimo, M., Tapanainen, J.S., 2001. Survival of human ovarian follicles from fetal to adult life: Apoptosis, apoptosis-related proteins, and transcription factor GATA-4. J. Clin. Endocrinol. Metab. 86, 3421-3429.

Vaskivuo, T.E., Maentausta, M., Torn, S., Oduwole, O., Lonnberg, A., Herva, R., Isomaa, V., Tapanainen, J.S., 2005. Estrogen receptors and estrogen-metabolizing enzymes in human ovaries during fetal development. J. Clin. Endocrinol. Metab. $90,3752-3756$.

Wassarman, P.M., 1988. Zona pellucida glycoproteins. Annu. Rev. Biochem. 57, 415442. 
Wassarman, P.M., 2005. Contribution of mouse egg zona pellucida glycoproteins to gamete recognition during fertilization. J. Cell Physiol. 204, 388-391.

Wassarman, P.M., Bleil, J., Fimiani C., Florman, H., Greve, J., Kinloch, R,. Moller, C., Mortillo, S., Roller, R., Salzmann, G.,Vazquez, M., 1989. The mouse egg receptor for sperm: a multifunctional zona pellucida glycoprotein. In The mammalian Egg Coat: Structure and function. Ed. J. Dietl. Springer Verlag, Berlin. pp. 18-37.

Yurewicz, E.C., Sacco, A.G., Gupta, S.K., Xu, N., Gage, D.A., 1998. Heterooligomerization-dependent binding of pig oocyte zona pellucida glycoproteins ZPB and ZPC to boar sperm membrane vesicles. J. Biol. Chem. 273, 7488-7494. 
1a. ZP3 mRNA
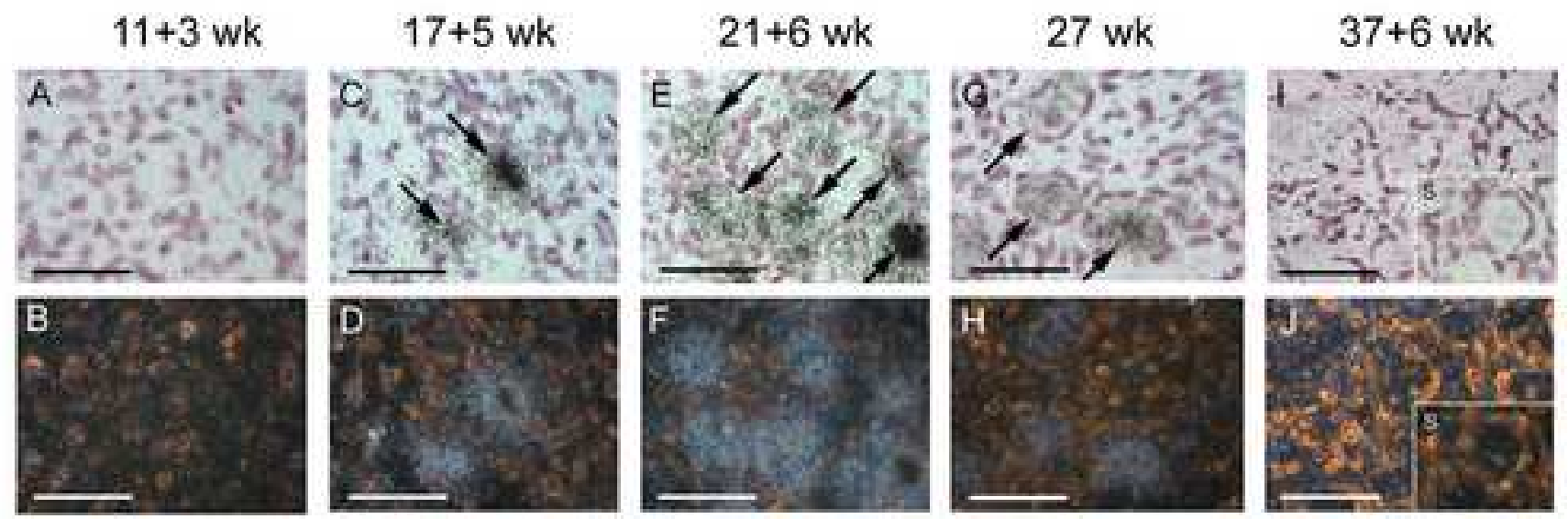

1b. ZP1 mRNA
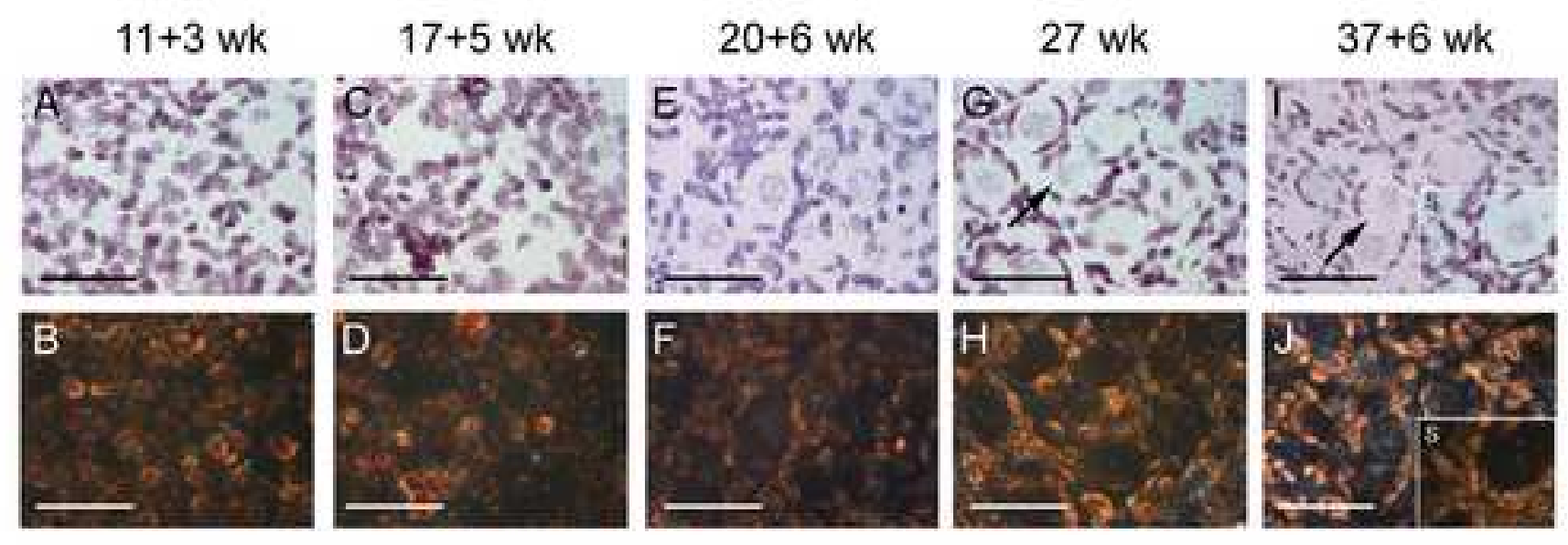

1c. FIGLA mRNA
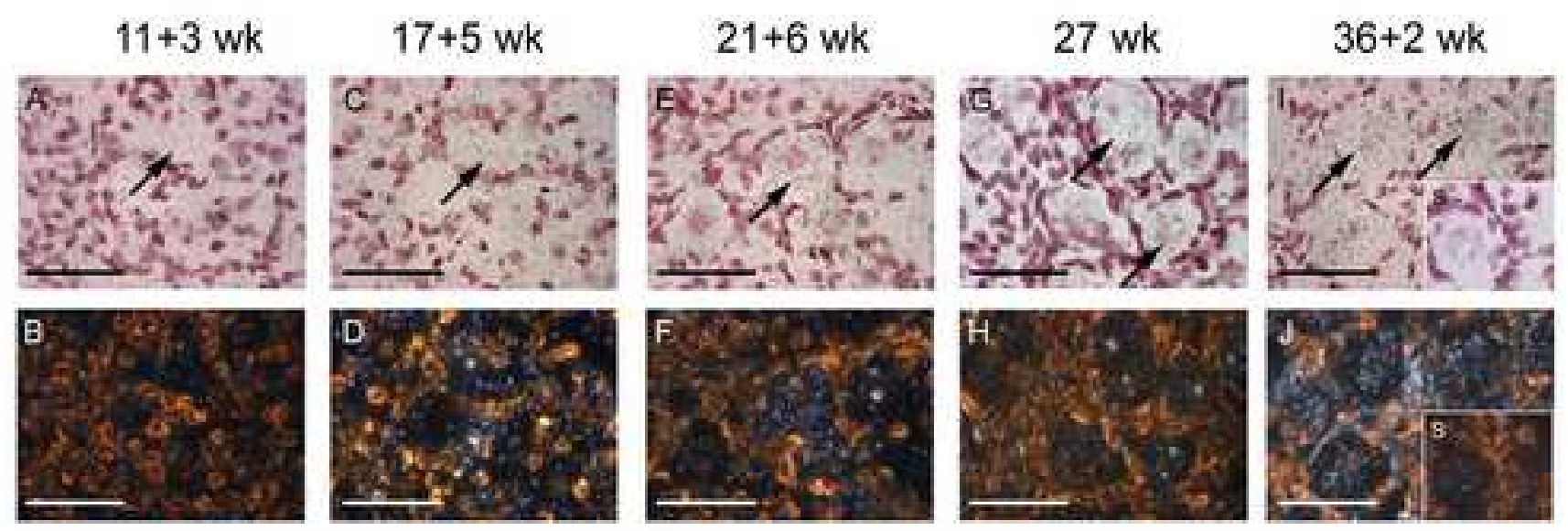

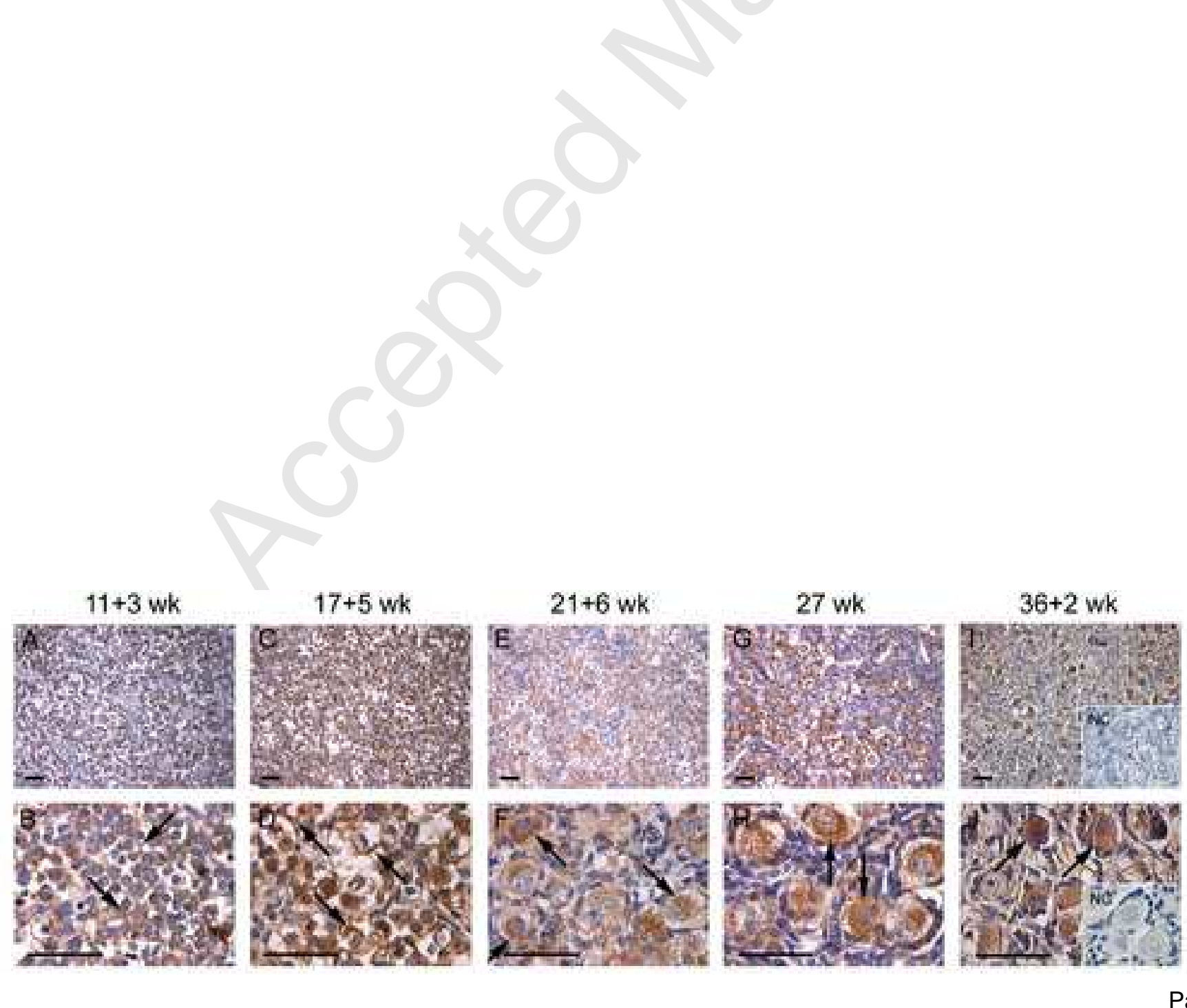

Page 23 of 24

Figure 2

Page 23 of 24

.

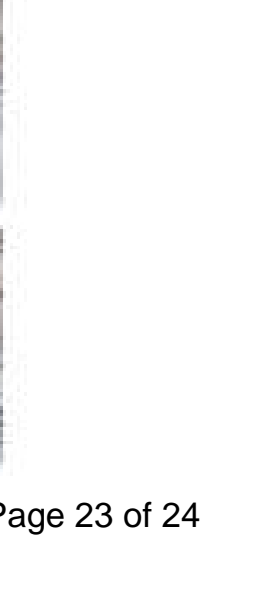




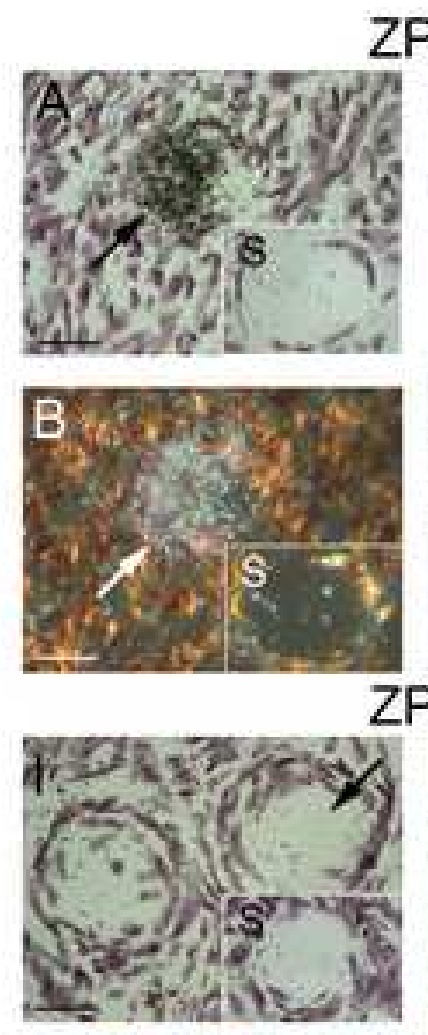

ZP3
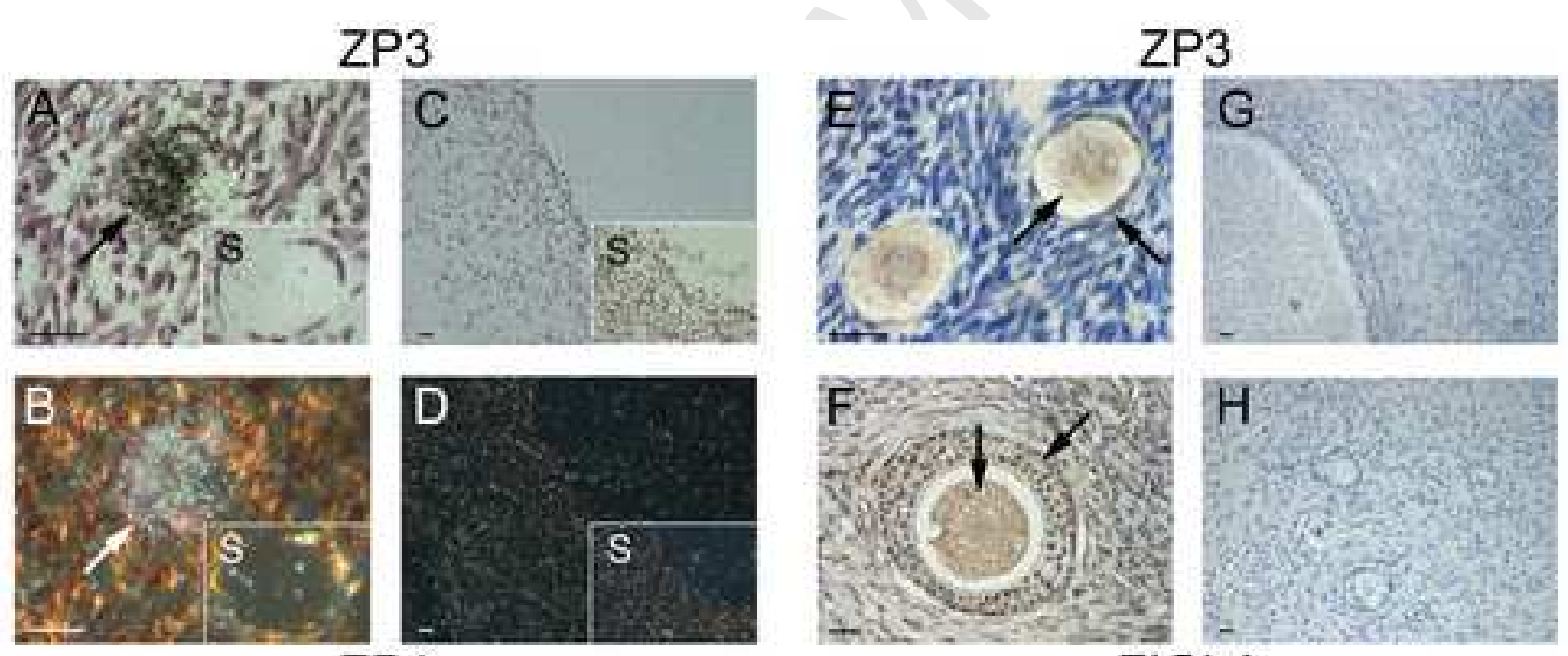

FIGLA
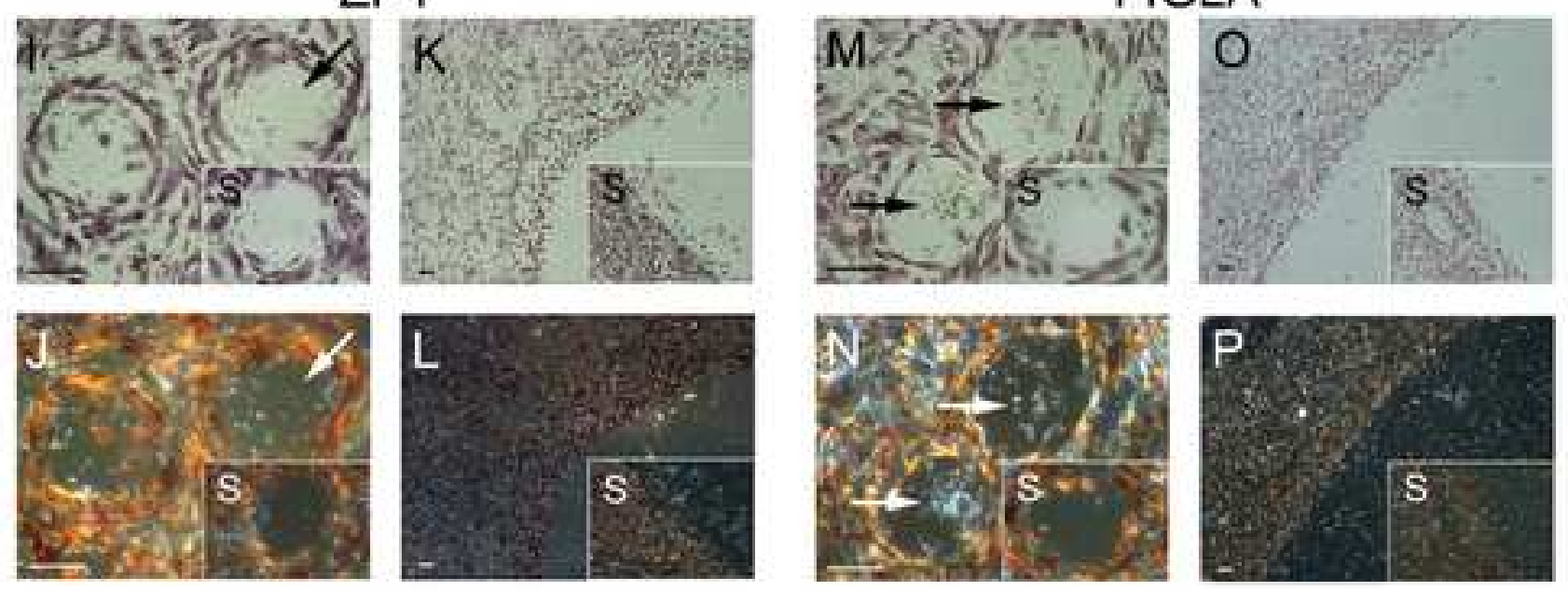